\title{
SHAREHOLDER PARTICIPATION IN ANNUAL GENERAL MEETINGS UNDER NIGERIAN CORPORATE LAW: PHILOSOPHY, PRACTICE AND THE ROLE OF SHAREHOLDER ASSOCIATIONS
}

\section{${ }^{1}$ Shamsuddeen Magaji, ${ }^{2}$ Nurli Yaacob \& ${ }^{3}$ Zuryati Mohamed Yusoff}

\author{
${ }^{1,2,3}$ School of Law, College of Law, Government and International \\ Studies, Universiti Utara Malaysia \\ ${ }^{1}$ Department of Islamic Law, Faculty of Law, Bauchi State \\ University, Gadau, Bauchi State, Nigeria
}

\author{
deeneemagaji@gmail.com; nurli@uum.edu.my; \\ zuryati@uum.edu.my
}

Received: 25 January 2018 Accepted: 8 July 2018 Published Online: 24 December 2018

\begin{abstract}
Shareholders and board of directors in an Annual General Meeting (AGM) are the two organs of a company. Shareholders are legally empowered to participate in the AGM to meet directors and know about the performance of the company. Despite various philosophies (theories) and legal provisions on shareholder participation in AGMs, shareholders are still facing some challenges. Moreover, available literature in this area is limited in Nigeria. Therefore, this study seeks to examine various philosophies (theories), the law, cases and opinions of experts on shareholder participation, practices and the role of shareholder associations in protecting the rights of shareholders. The study adopted two methods of data collection. The first method was doctrinal legal research (library based) which mainly concerned statutory provisions under the Companies and Allied Matters Act 1990 (CAMA) and decisions of the court. The second method of data collection consisted of qualitative interviews with seventeen respondents regarding the theories, practices and role of shareholder associations in protecting the rights of shareholder participation in AGMs. The findings showed that shareholder participation can be supported by various theories
\end{abstract}


including corporate personality theory; agency theory; contract theory; shareholder primacy; and corporate governance. The finding equally indicated that shareholders in Nigeria received notices of AGMs late, due to postal inefficiency and lack of recognition of ICT under the CAMA. Similarly, both regulators and shareholder associations have not done enough to protect shareholders and to improve their participation in AGMs. In view of this, there is a need for proactive measures to improve the participation of shareholders in AGMs. This is by amending the CAMA to incorporate provisions that will facilitate the effective service of notices of AGMs. Similarly, shareholder associations and regulators must take the responsibility of enlightening shareholders on their right of participation as well as how to enforce their rights in AGMs.

Keywords: Shareholders, Annual General Meeting, Shareholder associations.

\section{INTRODUCTION}

Members of a company play a vital role at a general meeting by way of direct participation in running the affairs of the company. They must be treated fairly, regardless of the percentage of their shareholding in the company and generally, are entitled to enjoy some basic rights provided under the law. They have the right to access relevant information regarding the performance of the company. Thus, the relationship that exists between members and the company itself is a contractual one which allows the members to influence corporate decisions to a certain extent as underlined by the company's articles of association.

Section 63 of the CAMA distributes corporate powers between the board of directors and shareholders in the annual general meeting (AGM). The board is in charge of the day-to-day activities of the company because it is difficult for all the shareholders to participate in the management of the company. ${ }^{1}$ Accordingly, the board of

Apostolides, N. (2007). Directors Versus Shareholders: Evaluating Corporate Governance in the UK Using the AGM Scorecard. Corporate Governance: An International Review, 15(6), 1277-1287; Kotoye v. Saraki [1994] 7 NWLR 414 at 467; Galbreath, J. (2017). The Impact of Board Structure on Corporate Social Responsibility: A Temporal View. Business Strategy and the Environment, 26(3), 358-370. 
directors owes a fiduciary duty to act in the best interest of the company. ${ }^{2}$ The board is also accountable to the shareholders in the general meeting. ${ }^{3}$ In this regard, sections 81, 213, 227(1), and 228 of the CAMA recognised the right of shareholders to receive notice; attend and vote in AGMs. In the English case of Sharp v. Dawes, ${ }^{4}$ 'meeting' is defined as a gathering of two or more persons whose aim is to discuss issues of mutual interest. In some jurisdictions, a single person can hold a valid meeting. Shareholder meeting is an assembly of shareholders having the right to attend, and vote in the meeting. ${ }^{5}$ According to section 65 of the CAMA, decisions taken in the meeting is regarded as the decisions of the company. In fact, the importance of AGMs cannot be overstated. In the case of New Resources International Ltd \& Anor v. Ejike Oranusi, ${ }^{6}$ the Court of Appeal of Nigeria held that the decision of a company is taken at the AGM or the board of director's meeting through a resolution. Therefore, shareholders' attendance in an AGM is an opportunity for shareholders to know the performance of a company through the presentation of a statutory report. ${ }^{7}$ It is also a forum where the conduct of directors is being scrutinised. ${ }^{8}$ The AGM contributes towards the enhancement of good corporate governance by making the directors accountable. ${ }^{9}$ In the AGM shareholders exercise their right including the removal of directors based on section 262 of the CAMA.

2 Anandarajah, K. (2001). Corporate Governance. A Practical Approach. Asia: Butterworth; Ajoku, O. O. (2014). Demythification of the organic theory of company law through the lens of corporate governance jurisprudence: Revisiting shareholder's activism (Case Study of Nigeria's Company and Allied Matters Act, 2004).

3 Brudney, V. (1996). Contract and Fiduciary Duty in Corporate Law. BCL Rev. 38, 595.

4 (1876) 2 QDB 29.

5 Hayati A.S. \& Hasani, M. A. (2015). A Legal Perspective of Shareholders' Meeting in the Globalised and Interconnected Business Environment. Global Conference on Business \& Social Science-2014, GCBSS-2014, 15th \& 16th December, Kuala Lumpur.

6 (2011) 2 NWLR (Pt 1230) 102.

7 Fox, J. (2008). Applied Corporate Governance: Call for Reform of AGM. Keeping Good Companies, 60(5), 270; Nelson, D. (2015). The Dilemma of the Shareholders Under the Nigerian Company Law, Journal of Policy and Globalisation.

8 Proctor, G., \& Miles, L. (2003). Corporate Governance. London: Cavendish Publishing Limited.

9 Rachagan, S., Pascoe, J. \& Joshi, A. (2010). Concise Principles of Company Law in Malaysia. 2nd edition. 
Section 213 of the CAMA states that an AGM shall be held every year, apart from other classes of meeting held by the company. There must be at least fifteen months between the first AGM and the next AGM. In the event a company held its AGM within eighteen months of its incorporation, such a company may not hold its next AGM in the subsequent year. However, a default in holding an AGM within the stipulated period may entitle a shareholder to apply to the Corporate Affairs Commission (CAC) to call an AGM. The CAC was established by section 7 of the CAMA as a regulatory body to monitor the operation of the CAMA among other functions. Where there is default in calling an AGM, a shareholder/member may apply to the CAC for direction to call the AGM. The CAC may direct a shareholder to call and conduct an AGM. Based on section 213(2) of the CAMA any decision taken shall bind all other shareholders and directors of the company. Similarly, a fine of five hundred Naira ( $\$ 500.00 /$ less than two pounds), is imposed on every director or officer of the company in default. Shareholder participation in an AGM is low despite its importance. Part of the reasons for the low participation is the delay in receiving notice of meeting ${ }^{10}$ and lack of transparency in the voting process ${ }^{11}$. On the one hand, shareholder activism through shareholder association is also less effective in improving shareholder participation in AGMs. In this regard, a brief discussion on shareholder activism and the role of shareholder association is given.

Shareholder activism originated from the United States and may have been successful across the globe. ${ }^{12}$ It is a process through which shareholders assert their power as owners of a company in order to influence the manner in which the company is governed. ${ }^{13}$

10 Atte, B. (2015). Enhancing Shareholder's Participation in Company Meetings in Nigeria Through Application of Information Technology. Journal of Humanities and Social Science 20(9); Respondent 3 (Lecturer), interviewed by researcher, Nigeria, October 26, 2016.

11 Respondent 2 (Lecturer), interviewed by researcher, Nigeria, October 27, 2016.

12 Robin, H. Q. C. (2013). Hollington on Shareholders' Rights, $17^{\text {th }}$ edition. United Kingdom: Sweet \& Maxwell Limited; Magaji, S. (2018). Improving Member's Participation in the Annual General Meeting under Nigerian Corporate Law. Unpublished PhD Thesis. Universiti Utara Malaysia.

13 European Corporate Governance Institute, http://www.ecgi.org/activism/index. php. (accessed March_25, 2017); Goranova, M., Abouk, R., Nystrom, P.C, \& Soofi, E. S. (2017). Corporate Governance Antecedents to Shareholder Activism: A Zero-Inflated Process. Strategic Management Journal, 38(2), 415-435. 
In other words, it is an intervention by shareholders in running the affairs of the company which encompasses a wide range of activities, including voting, shareholder participation and election of members of the board of directors among others. ${ }^{14}$ Various reasons are given for shareholder activism. However, it is prominently linked to principal/ agent relationship. ${ }^{15}$ It is in this regard that shareholder activism mitigates the likelihood of self-dealing by management as well as protects the interest of members ${ }^{16}$ and reconciles agency problems between shareholders and the management. ${ }^{17}$ It is equally regarded as a market means of governance that ensures monitoring activities of the management toward shareholder value and protection as well as defence against managerial deviations. ${ }^{18}$

In spite of the fact that there are challenges that affect shareholder participation in AGMs, there is a dearth of literature regarding AGMs in Nigeria as even an Internet search would reveal this fact. The objective of this study is to underpin relevant philosophies (theories); legal provisions; and opinions of experts (respondents) which support shareholder participation in AGMs in Nigeria. Furthermore, the role of regulators and shareholder associations in protecting shareholders as well as improving their participation in AGMs would be examined.

\section{METHODOLOGY}

This study adopted two methods of data collection. The first method was doctrinal legal research which was library-based.$^{19}$ In this regard, it mainly concerned statutory provisions of the CAMA; decided

14 Worthington, S. (2001). Shareholders: Property, Power and Entitlement, part 1 \& 2, Vol.22 Company Lawyer 258.

15 Jensen, Mc. \& Meckling, W.H. (1976). Theory of the Firm: Managerial Behaviour, Agency Costs and Ownership Structure. Journal of Financial Economics (3) 305.

16 Beebchuk, L.A. (2005). The Case for Increasing Shareholder Power. Harvard Law Review, 118833.

17 Fama, E. F. \& Jensen, M. C. (1983). Separation of Ownership and Control. Journal of Law and Economics, (26) 301.

18 Hirschmann, A. O. (1976). Exit, Voice and Loyalty: Responses to Decline in Firms, Organisations, and States.. Cambridge, MA: Harvard University Press

19 Yaqin, A. (2007). Legal Research and Writing. Lexis Nexis. 
cases; and authored work. Doctrinal method is problem-solving in nature. ${ }^{20}$ The second method of data collection was qualitative interviews which comprised derived data from the opinion of respondents. ${ }^{21}$ The qualitative method enabled the researchers to analyse the opinion of respondents and present logical findings. ${ }^{22}$ In this study, seventeen respondents were interviewed on theories relating to shareholder participation in AGMs as well as the role of regulators and shareholder associations on shareholder participation in AGMs. The respondents were chosen from among academics and shareholder activists based on their practical experience and expertise which added value to this study. The interviews were conducted face-to-face with the respondents, ${ }^{23}$ across various states in Nigeria. The data was recorded using an audio device and transcribed ${ }^{24}$ for analysis. The data was analysed based on content and themes of the study. ${ }^{25}$

\section{FINDINGS AND DISCUSSION}

Various theories including corporate personality theory, agency theory, contract theory, shareholder primacy, and corporate governance theory implicitly recognise participation of shareholders in AGMs. Although, the above theories are not specifically modelled on shareholder participation in AGMs they can be linked with shareholder participation in AGMs. Moreover, the provision of the CAMA, decided cases and opinion of the respondents indicated

Dent, C. (2017). A Law Student-Oriented Taxonomy for Research in Law. Victoria U. Wellington L. Rev., 48, 371.

21 Seidman, I. (2013). Interviewing as Qualitative Research: A Guide for Researchers in Education and the Social Sciences. New York \& London. Teachers College, Columbia University.

22 Lea, S. (2012). Qualitative Data Analysis. Seminar for the Academic Swiss Caucasus Net. Armenia.

23 Sturges, J. E., \& Hanrahan, K. J. (2004). Comparing Telephone and Face-ToFace Qualitative Interviewing: A Research Note. Qualitative Research, 4(1), 107-118; Dicicco-Bloom, B., \& Crabtree, B. F. (2006). The Qualitative Research Interview. Medical Education, 40(4), 314-321.

24 Henderson, H. (2018). Difficult Questions of Difficult Questions: The Role of the Researcher and Transcription Styles. International Journal of Qualitative Studies in Education, 31(2), 143-157.

25 Boyatzis, R. E.(1998). Transforming Qualitative Information: Thematic Analysis and Code Development. Sage; Green, J., \& Thorogood, N. (2018). Qualitative Methods for Health Research. Sage. 
that the above theories support shareholder participation in AGMs. The opinion of the respondents in this regard is to demonstrate the nexus between the above theories and shareholder participation in AGMs. The findings also indicated that regulators and shareholder associations are not doing enough towards improving shareholder participation in AGMs.

\section{Corporate personality theory}

Starting with the corporate personality theory, the term 'corporation' derived its meaning from the Latin word 'corporatus' which means a body or group of persons that come together for a mutual purpose. ${ }^{26}$ However, whether this body or group had separate rights distinct from individual members was the subject of discussion by German and French philosophers in the nineteenth century. ${ }^{27}$ This necessitated various theories of corporate personality which included the creature theory; fiction theory; and concession theory. The creature theory propounded by Savigny believed in the individual nature of a person, which conferred certain inalienable rights duly recognised by the law. ${ }^{28}$ Savigny argued that there was a legal relationship between one person and another. Therefore, individuals were free to form an association without an independent existence on its own. ${ }^{29}$ However, the law recognised the status of this body as an 'artificial or juristic person.' The fiction theory, on the one hand, recognised the corporation as a legal fiction. ${ }^{30}$ This theory viewed corporations as natural persons even though there are obvious differences between a natural person and a corporation. ${ }^{31}$ However, there must

26 Schane, S. A. (1987). The Corporation is a Person: The Language of Legal Fiction, 61 Tul. L. Rev. 563.

27 Katsuhito, I. (1999). Persons, Things and Corporations: The Corporate Personality Controversy and Comparative Corporate Governance, American Journal of Comparative Law 47(4), 583-632.

28 George, H. Ed. (1977). Associations and Law: The Classical and Early Christian Stages. Toronto: University of Toronto Press.

29 Iwai, K. (1999). Persons, Things and Corporations: The Corporate Personality Controversy and Comparative Corporate Governance. The American Journal of Comparative Law, 47(4), 583-632.

30 Radin, M. (1932). The Endless Problem of Corporate Personality. Columbia Law Review, 32(4), 643-667.

31 Maximilian, K. (1949). Person in Imagination or Persona Ficta of The Corporation," 9 La. L. Rev. 437; Wells, H. (Ed.). (2018). Research Handbook on the History of Corporate and Company Law. Edward Elgar Publishing. 
be natural persons (in the form of directors) to run the affairs of the company. ${ }^{32}$ The concession theory, on the one hand, argued that corporate personality is a result of state law. ${ }^{33}$ It cannot be conferred by anybody apart from the law of a state. In this regard, section 37 of the CAMA recognised that a company after incorporation acquired the status of a corporate body with all powers including the power to hold land, perpetual succession and a common seal among others.

The above provision recognised a company as a legal person that is distinct and separate from the shareholders. ${ }^{34}$ The above principle was codified under the CAMA based on the famous case of Salomon v. Salomon. ${ }^{35}$ In the same vein, various decisions of Nigerian courts pronounced on the corporate personality principle. ${ }^{36}$ This theory is the foundation of the present corporate law regarding shareholders and the company as two separate entities. ${ }^{37}$ In view of this there is the need for shareholders and the management to meet for the directors to account for their stewardship. ${ }^{38}$ This is only possible through the participation of shareholders in the AGM. ${ }^{39}$ According to Respondent $1,{ }^{40}$ "From the day a company is incorporated, certain organs are immediately put in place. One of such organs is the board of directors and the shareholders in the general meeting. The directors and shareholders must meet in the annual general meeting." From the provision of section 37 of the CAMA, decided cases and the opinion of Respondent 1 prior this, it may be argued that corporate personality principle is recognised under Nigerian corporate law. Similarly, there is recognition by shareholders to participate in AGMs as the only forum for shareholders to meet directors.

32 Ghadas, Z. A. A. (2007). Real or Artificial-Jurisprudential Theories on Corporate Personality. US-China Law Review, 4, 6.

33 Robert, H. (1979). New Concept of Corporations: A Contractual and Private Property Model. 30, Hastings L. J. 1327.

34 Ndzi, E. (2017). The impact of the Salomon Principle on Directors' Remuneration in the UK. International Journal of Law and Management, 59(2), 257-270.

35 (1879) AC 22.

36 M. A. Omisade \& Ors v Harry Akande (1987) LPELR 2639 S.C.; Tsokwa Oil Marketing Co. v. U.T.C. (Nig.) Plc (2002) 12 NWLR (Pt 52) 437 C.A.

37 Iwai, K op cit.

38 Kaler, J. (2002). Responsibility, Accountability and Governance. Business Ethics: A European Review, 11(4), 327-334.

39 Cordery, C. J. (2005). Annual General Meeting as An Accountability Mechanism. Working Paper No.23, University of Wellington, New Zealand.

40 Respondent 1 (Lecturer), interviewed by researcher, Nigeria, November 6, 2016. 


\section{Agency theory}

This theory views a corporation as a relationship between individuals with a common interest. ${ }^{41}$ Jensen and Meckling argued that agency theory regulates the relationship between a principal and the agent. In a corporation, shareholders are deemed to be the principal while the board of directors is regarded as the agent. ${ }^{42}$ Shareholders invest their resources and empower the board of directors to act on their behalf. This is because, in many instances, it is difficult for shareholders to possess both the capital and the expertise to manage a company. ${ }^{43}$ However, the problem(s) arises in the relationship between shareholders and the board. Arnold and de Lange pointed out that risk tolerance is viewed differently by shareholders and the board. ${ }^{44}$ While shareholders are concerned with high returns on investment, the board is more interested in what they will gain. ${ }^{45}$

At certain times, shareholders are not sure about the performance of the board regarded as 'agent' ${ }^{46}$ Moreover, there is a conflict of interest regarding decision-making. Shareholders always want lasting solutions while the board may proffer short-term solutions so that their performance would be appreciated. ${ }^{47}$ This theory emphasised the use of proper control mechanisms between the shareholders and the board that ensures reduction in cost of monitoring the activities of the board..$^{48}$ This is possible through the exercise of voting rights

${ }^{41}$ Jensen, M. C., \& Meckling, W. H. (1976). Theory of The Firm: Managerial Behavior, Agency Costs and Ownership Structure. Journal of Financial Economics, 3, 305-360; Rashidah A., \& Mohammad R.Salim. (2010). Corporate Governance in Malaysia: Theory, Law and Context. Malaysia: Sweet \& Maxwell.

42 Conyon, M. J., \& Leech, D. (1994). Top Pay, Company Performance and Corporate Governance. Oxford Bulletin of Economics and Statistics, 56(3), 229-247.

43 Claire E. C., \& Robert S. H. (1989). A Test of The Agency Theory of Managerial Ownership, Corporate Leverage, and Corporate Dividends. Financial Management, 18(4), 36-46; Magaji, fn. 12.

44 Arnold, B., \& De Lange, P. (2004). Enron: An Examination of Agency Problems. Critical Perspectives on Accounting, 15(6), 751-765.

45 Simon, H. A. (1951). A Formal Theory of The Employment Contract. Econometrica, 19, 293-305.

46 Rashidah \& Mohamed, fn. 41.

47 Steven V. M., \& Neil W. S. (1991). Agency Costs of Free Cash Flow: Acquisition Activity and Equity Issues. Journal of Business, 64(2), 213-227.

48 Rashidah \& Mohamed, fn. 41. 
in the general meeting. ${ }^{49}$ There is the need for effective monitoring by shareholders. ${ }^{50}$ In this regard, sections 63 and 64 of the CAMA specifically distribute corporate powers between shareholders at the AGM and the board of directors. Respondent 3, "A "A company is a legal person. It can only operate through biological human beings (directors). Shareholders of the company must participate in decision-making and give directions that the company will follow." This necessitates for shareholders to checkmate the activities of the board which is only possible through AGMs.

\section{Contract theory}

This theory originated from the United States of America. ${ }^{52}$ The contract theory is one of the essential theories in corporate governance today..$^{53}$ This theory also emphasised on 'maximising self-interest' as the best monitoring mechanism. ${ }^{54} \mathrm{~A}$ company is viewed as a relationship consisting of different contracts entered by various stakeholders. ${ }^{55}$ Shareholders invest their capital to get a return and therefore, are entitled to all the excess profit left after settlement with other stakeholders. ${ }^{56}$ Shareholders here are given ultimate control on how the company is to be managed because they bear a high percentage of risk..$^{57}$ Accordingly, the AGM is the only forum for the shareholders to monitor the board. ${ }^{58}$ The AGM

49 Baums, T. (2000). General Meetings in Listed Companies - New Challenges and Opportunities, Company Law Reform in OECD Countries: A Comparative Outlook of Current Trends. Stockholm, Sweden.

50 Susan P. S. (2005). Agency Theory. Annual Review of Sociology, 31, 263-284.

51 Respondent 3 (Lecturer), interviewed by researcher, Nigeria, October 26, 2016.

52 Oliver, H. (1995). Corporate Governance: Some Theory and Implications. Economic Journal, 105(430), 678-689.

53 Shleifer, A., \& Vishny, R. W. (1997). A Survey of Corporate Governance. The Journal of Finance, 52(2), 737-783.

54 Easterbrook, F. \& Fischel, D. (1993). Contract and Fiduciary Duty. Journal of Law and Economics, 36, 425.

55 Fama, E. (1980). Agency Problems and The Theory of The Firm. Journal of Political Economy, 88, 288 At 290.

56 Johnson, A. (2007). After OFR: Can UK Shareholder Value Still Be Enlightened? European Business Organisation Law Review 7, 817 At 821.

57 Van Der Weide, M. (1996). Against Fiduciary Duties to Corporate Stakeholders. Journal of Corporate Law, 21, 27 At 57.

58 Apostolides, N., \& Boden, R. (2005). Cedric the Pig: Annual General Meetings and Corporate Governance in the UK. Social Responsibility Journal 1(1), 5362 . 
is conducted in fulfilment of the contractual agreement between shareholders and the board. ${ }^{59}$

In this regard, section 41 of the CAMA provides:

Subject to the provisions of this Act, the memorandum and articles, when registered, shall have the effect of a contract under seal between the company and its members and officers and between the members and officers themselves whereby they agree to observe and perform the provisions of the memorandum and articles, as altered from time to time in so far as they relate to the company, members, or officers as such.

The above provision makes it clear that a company's memorandum and articles of association has the effect of a valid contract between the company; shareholders; and the board. Thus, shareholders have the freedom to adopt any rule they agree to govern their relationship provided it is not against the law. ${ }^{60}$ This is contained in the articles of association and sometimes complemented by shareholders' agreement. ${ }^{61}$ The articles of association is a contractual obligation between the shareholders and the company. ${ }^{62}$ In the case of Longe v. FBN PLC, the Court of Appeal of Nigeria held that the powers vested on the board of directors was a contractual power that can only be taken by amendment. The memorandum and articles of association constituted a binding contract not only between the company and its shareholders but equally between individual shareholders themselves. ${ }^{63}$ Both the calling of an AGM and its

59 Chong, B. C., Ngee, P. K.T. \& Ling, P. SW. (2006). Chan \& Koh On Malaysian Company Law: Principles \& Practice. $2^{\text {nd }}$ Edition.

60 Robin, H. Q. C. (2013). Hollington on Shareholder's Rights, $17^{\text {th }}$ Edition. England: Sweet \& Maxwell.

61 Lucian, A. B. (2005). The Case for Increasing Shareholder Power. Harvard Law Review, 118(3), 833-914.

62 Kahn-Freund, O. (1940). Articles of Association and Contractual Rights. The Modern Law Review, 4(2), 145-148.

63 Yalaju Amaye v A. R.E.C (1990) 4 NWLR Pt. 145 422; NIB Investment WestAfrica v. Omisore (2006)4 NWLR Pt. 969172 at 200; Agbonika, J., Alewo, M., and Olong,M.A (2014). the legal effects of articles of association of a company: Perspectives on corporate governance in Nigeria. Journal of Law, Policy and Globalization 28, 124-128. 
conduct is regulated by the law as well as the article under section 33 and 213 of the CAMA. In this regard, Respondent 4 stated that: ${ }^{64}$

One of the organs through which decisions would be taken is the annual general meeting. That is why section 213 of the CAMA states that there must be an AGM once in a year. The management of a company has certain responsibilities, but certain powers are exclusively given to the general meeting, like a change of name, increase of capital, and reduction of capital. That is why you need shareholders at the general meeting.

\section{Shareholder primacy}

Shareholder primacy is another concept developed based on partnership principles. This concept contends that management of the business is totally within the control of the shareholders. The Companies Act of the United Kingdom which was the model for the CAMA stressed that shareholders are regarded as the most important organ of a company. ${ }^{65}$ The need for the enhancement of shareholder primacy is crucial regardless of any other object of a company. ${ }^{66}$ The Common law emphasised shareholder primacy on director's duty of loyalty to the company. ${ }^{67}$ This concept does not attach much significance to the interest of other stakeholders. ${ }^{68} \mathrm{In}$ the English case of Hutton v. West Cork Railway Co, Bowen LJ held that considering the interest of other stakeholders in a company is a qualified one. Directors are only obliged to consider the interest of other stakeholders where it would benefit the shareholders. This

64 Respondent 4 (Lecturer), interviewed by researcher, Nigeria, November 24, 2016.

65 Shuangge W. (2013). Shareholder Primacy and Corporate Governance: Legal Aspects, Practices and Future Direction. New York: Routledge Taylor \& Francis Group; Magaji. fn. 12.

66 Hampel Report on Corporate Governance: Finance Report (1998).

67 Davies, P., Worthington, S., \& Micheler, E. (2008). Gower And Davies: Principles of Modern Company Law $8^{\text {th }}$ Edition. London: Sweet \& Maxwell.

68 Shuangge, op cit. 
theory is relevant to the study for its recognition of shareholders as the most vital organ of a company. ${ }^{69}$ Respondent 3 stated: ${ }^{70}$

Shareholders are the primary stakeholders in every company. All their powers and rights are derived largely based on their investment in a company because they are the residual owners of a company. Having invested in the company it is only reasonable to expect that they should have a say on the running of the company and that is why the law expressly recognises some number of rights or powers vested in them.

\section{Concept of corporate governance}

There is no specific definition on the concept of corporate governance. According to the Cadbury Report on Financial Aspect of Corporate Governance 1992, corporate governance is a system whereby companies are 'directed and controlled.' The Hampel Committee adopted this definition on Corporate Governance, 1998. According to the Organisation for Economic Co-operation and Development (OECD), corporate governance means:

The system by which business corporations are directed and controlled. The governance structure specifies the distribution of rights and responsibilities among different participants in the corporation such as the board, managers, shareholders and other stakeholders and spells out the rules and procedures for making decisions on corporate affairs. By doing this, it also provides the structure through which objectives are set, and the means of attaining those objectives and monitoring performance. ${ }^{71}$

69 Kucukyalcin, E. (2018). Converging the Shareholder and Stakeholder Theories. In Sustainability and Social Responsibility: Regulation and Reporting 203-223. Springer, Singapore.

70 Respondent 3 (Lecturer), interviewed by researcher, Nigeria, October 27, 2016.

71 Richard, S. (2010). Practical Guide to Corporate Governance $4^{\text {th }}$ Edition. United Kingdom: Sweet \& Maxwell. 
The above definition recognised distribution of rights between the board and shareholders as well as monitoring the activities of the board by shareholders. Accordingly, corporate decisions must reflect certain values including accountability and transparency. ${ }^{72}$ This helps in making sound corporate decisions. Two main theories of corporate governance reflected in most of the previous studies are shareholder value theory and stakeholder theory. Shareholder value theory emphasised the interest of shareholders above any other stakeholder in a company ${ }^{73}$ just like the concept of shareholder primacy. This theory recognised shareholder interest as paramount beyond any other interest in the company. According to Respondent $2,{ }^{74}$ "Shareholder participation at the annual general meeting is recognition that they have interest that is above the interest of other stakeholders. Shareholders must participate in the AGM. It is an indispensable right that must be respected." This equally recognised shareholder participation at the AGM as very crucial. ${ }^{75}$

\section{Regulatory institutions}

The two regulatory institutions in Nigeria are the Corporate Affairs Commission (CAC) and the Securities and Exchange Commission (SEC). The CAC was established by section 7 of the CAMA as a regulatory body to monitor the enforcement of the provision of the CAMA. The SEC on the one hand was established by the Investment and Securities Act 2007 as a corporate regulator as well as the apex regulator concerning capital market. Accordingly, corporate regulators have a significant impact in ensuring compliance with relevant laws and rules by the board of directors. Today, regulators institute cases against the board of directors for breach of their

72 Luo, Y. (2005). Corporate Governance and Accountability in Multinational Enterprises: Concepts and Agenda. Journal of International Management, 11(1), 1-18; Du Plessis, J. J., Hargovan, A., \& Harris, J. (2018). Principles of contemporary corporate governance. Cambridge University Press.

73 Lazonick, W., \& O'Sullivan, M. (2000). Maximizing Shareholder Value: A New Ideology for Corporate Governance. Economy and Society, 29(1), 13-35.

74 Respondent 2 (Lecturer), interviewed by researcher, Nigeria, October 27, 2016.

75 Owusu, A., \& Weir, C. (2018). Agency Costs, Ownership Structure and Corporate Governance Mechanisms in Ghana. International Journal of Accounting, Auditing and Performance Evaluation, 14(1), 63-84. 
duties. ${ }^{76}$ However, regulators in Nigeria, arguably, are not doing enough to see that shareholders participate at AGMs. In this regard, the Director General of the CAC believed that the current provision of the CAMA which is a legislation of more than 20 years, prevents the CAC from fully exercising its regulatory and enforcement functions. He calls for a substantial amendment of the CAMA. ${ }^{77}$ From the perspective of the respondents, Respondent 2 argued: "We have weak regulatory infrastructure in Nigeria. The surveillance, monitoring, and enforcement are very low." ${ }^{\prime 78}$ Another Respondent ${ }^{79}$ added that, "The regulatory bodies are not doing enough. They are only concerned with how to raise money. They are expected to regulate, but now they are acting as government revenue collectors." The majority of the respondents argued that regulators are not doing enough to see that shareholders are enlightened to participate in AGMs.

\section{Shareholder associations in Nigeria}

The question now is, to what extent do shareholder associations protect the interest of its members? This is made possible through various changes to the code of corporate governance and the forming of shareholder associations. Accordingly, Rule 26 of the Code of Corporate Governance for Public Companies in Nigeria 2011 (CCGPCN) tasks the management to ensure fair and transparent dealings with shareholder associations. This rule, not only recognised the forming of shareholder associations, but, rather transparency in their dealings. Although, recently, the Financial Reporting Council has issued a draft of the Nigerian Code of Corporate Governance (NCCG 2018) which has suspended the earlier code. The fact is that the codes recognised shareholder associations.

76 Ramsay, I. (2015). Increased Corporate Governance Powers of Shareholders and Regulators and the Role of the Corporate Regulator in Enforcing Duties Owed by Corporate Directors and Managers." European Business Law Review 26(1), 49-73.

77 "20 Years after Enactment, CAC RG Calls for Amendment of CAMA." http:// new.cac.gov.ng/home/20-years-after-enactment-cac-rg-calls-for-amendmentof-cama/ (accessed November 17, 2017).

78 Respondent 2 (Lecturer), interviewed by researcher, Nigeria, October 27, 2016.

79 Respondent 8 (Shareholder activist), interviewed by researcher, Nigeria, December 12, 2016. 
The Nigerian government established various shareholder associations. In 1992, zonal headquarters was established alongside seven (7) zonal offices. They were located in seven different states of the federation, namely: Rivers, Kaduna, Jos, Kano, Lagos, Anambra and Oyo. These associations were all incorporated with the CAC. The SEC also regulates the activities of shareholder associations through its code for shareholders associations. ${ }^{80}$ This gives an opportunity for shareholders to be represented by their association on the board. ${ }^{81}$ The executive council of these associations is responsible for educating shareholders and keeping a record of them within their respective zones. ${ }^{82}$ Shareholder associations protect the interest of investing shareholders who have the opportunity to contribute to the formulation of broad corporate policies thereby enhancing management accountability and transparency. ${ }^{83}$ Some of the duties of these associations include educating shareholders on their rights and responsibilities and right of participation in corporate decisionmaking through regular attendance of company meetings. ${ }^{84}$

There are also various independent associations of shareholders in Nigeria which aim to protect shareholders. ${ }^{85}$ Accordingly, shareholders have challenged decisions of management which had not acted in the best interest of the company. ${ }^{86}$ Unfortunately, some executives of these associations prioritised their selfish interest against that of the shareholders. In fact, they failed in educating

Ruth, P. (2011). Shareholders Associations and Rest of Us. http://www. vanguardngr.com/2011/09/ (accessed April 25, 2017).

81 Newman, C. E., \& Chibuike, O. O. (2014). Corporate Governance Reforms in Nigeria: A Study of Shareholders' Right of Entry. http://papers.ssrn.com/sol3/ papers.cfm?abstract_id=2397377 (accessed April 25, 2016).

82 Amao \& Amaeshi.

83 Etukudo. A (2000). Issues in Privatization and Restructuring in Sub-Saharan Africa - Interdepartmental Action Programme on Privatization, Restructuring and Economic Democracy Working Paper IPPRED 5. http://www.ilo.org/public/ english/employment/ent/papers/ippred5.htm (accessed March 29, 2017). Ibid.

85 Sola, E. O. (2016). Role of Shareholders in Implementing the Code of Corporate Governance. http://www.businessdayonline.com (accessed February 27, 2016).

${ }^{86}$ Okike, E. N. M. (2007). Corporate Governance in Nigeria: the status quo' Corporate Governance: An International Review, 15(2) 173-193. 
shareholders on their rights and how to exercise them. ${ }^{87}$ Moreover, there is no provision under the CAMA that recognised shareholder associations. In spite of this, there is a Companies and Allied Matters Bill 2018 which is awaiting assent.

\section{Opinion of respondents from qualitative interviews on the role of shareholder associations in improving shareholder rights of participation in AGMs}

In this regard, thirteen respondents out of seventeen were interviewed on the role of shareholder associations towards improving and protecting the rights of shareholders. Ten respondents out of thirteen argued that shareholder associations were not doing enough to protect shareholders. From some of the excerpts, Respondent 5 was of the view that, "Shareholder associations have been in existence and they have always been conniving with management to perpetuate whatever the management wants." ${ }^{88}$ Respondent 7 added, "Shareholder associations are not doing their jobs. I do not think they are representing the shareholders." ${ }^{89}$ In his response, Respondent 12 , added, "The main problem is, there is no control in the shareholder association. Before the AGM, we receive calls to the extent we do not want the AGM to come up because everybody is a registered shareholder association. It is more of protecting the personal interests of leaders of the associations than the shareholders." 90

However, Respondent 17 believed, "There should be enlightenment which is essential. Then, shareholder association should have a role to play because it is a collective decision; it is easier to get justice going to court through the shareholder association than going to court as an individual." ${ }^{91}$ This explains the need to have shareholder

87 Rotimi, B. (2015). A Minority Shareholder. http://www.daargroup.com/ daar-group/latest-news/vanguardngr-shareholders-associations-losing-focus. (accessed March 17, 2015). ${ }^{88}$ Respondent 5 (Lecturer), interviewed by researcher, Kano, Nigeria, October 25, 2016.

89 Respondent 7 (Shareholder activist), interviewed by researcher, FCT Abuja, Nigeria, October 27, 2016.

90 Respondent 12 (Company Director), interviewed by researcher, Kano, Nigeria, November 22, 2016.

91 Respondent 17 (Regulator), interviewed by researcher, FCT Abuja, Nigeria, November 22, 2016. 
associations to represent the interest of other members in educating them to attend AGMs and to enlighten them about their rights and how to enforce these rights. Respondent 17 further stated, "At times, the AGMs are teleguided because most of the shareholders are participating through shareholder associations and companies fund most of these associations. Therefore, the associations are indirectly controlled by the management." 92 According to Respondent 16, "Nigeria is a wonderful country and that is why people are rushing to get this kind of engagements (shareholders association) for their personal interests." 93

On the other hand, three of the respondents argued that shareholder associations in Nigeria are protecting the interests of the shareholders. Respondent 16 claimed: ${ }^{94}$ "To some extent, shareholder associations are doing their best to protect the interests of shareholders."

The opinion of the respondents indicated that shareholder associations that were formed to protect the interest of shareholders have been compromised. This puts shareholders in a challenging situation because both the regulators and the associations they (shareholders) formed are not meeting up to expectations in educating the shareholders on the importance of participating in AGMs. Similarly, the regulators and shareholder associations have failed in their duty to inform shareholders of their rights and the enforcement process.

\section{CONCLUSION}

Shareholder participation at AGMs is a personal and indispensable right that belongs to shareholders based on sections 81 and 213 of the CAMA. Accordingly, shareholders rely on AGMs as a forum to exercise their rights, and any violation of this right will entitle a shareholder(s) to seek redress. Shareholder participation in decision-

92 Respondent 17 (Regulator), interviewed by research er, FCT Abuja, Nigeria, November 22, 2016.

93 Respondent 16(Regulator), interviewed by researcher, Kano, Nigeria, November 21, 2016.

94 Respondent 16(Regulator), interviewed by researcher, Kano, Nigeria, November 21, 2016. 
making is the key to any reform that seeks shareholder remedies. ${ }^{95}$ The discussion in this study has indicated that shareholder participation at AGMs has been recognised from the legal and philosophical perspective as well as from the opinions of respondents. However, one may be interested to know whether in practice shareholders do participate in AGMs in Nigeria. Admittedly, various challenges affect shareholder participation in AGMs including delays in receiving notices since there is no provision under the CAMA that recognise the application of ICT in serving notices of meetings. Despite this, there have been attempts to remedy some of these challenges through the Companies and Allied Matters Bill 2018 which is awaiting assent. Furthermore, both regulators and shareholder associations must exercise their responsibility not only in imposing fines but rather on educating shareholders on the importance of participating in AGMs as well as raising shareholders awareness regarding their rights and how to enforce them.

\section{BIBLIOGRAPHY}

Agbonika, J., Alewo, M., \& Olong, M. A (2014). The Legal Effects of Articles of Association of a Company: Perspectives on Corporate Governance in Nigeria. Journal of Law, Policy and Globalization 28, 124-128.

Ajoku, O. O. (2014). Demythification of the Organic Theory of Company Law Through the Lens of Corporate Governance Jurisprudence: Revisiting Shareholder's Activism (Case Study of Nigeria's Company and Allied Matters Act, 2004). Anandarajah, K. (2001). Corporate Governance. A Practical Approach. Asia: Butterworth.

Apostolides, N. (2007). Directors Versus Shareholders:

Evaluating Corporate Governance in The UK Using the AGM Scorecard. Corporate Governance: An International Review, 15(6), 1277-1287.

95 Rachagan, S. \& Mohd Sulaiman, A. (2018). Expanding Shareholders' Power: An Analysis of Reform Proposals in Malaysia. Review of Law \& Economics. Retrieved 11 Mar. 2018, from doi:10.1515/rle-2015-0041 
Apostolides, N., \& Boden, R. (2005). Cedric The Pig: Annual General Meetings and Corporate Governance in the UK. Social Responsibility Journal 1(1), 53-62.

Arnold, B. \& De Lange, P. (2004). Enron: An Examination of Agency Problems: Critical Perspectives on Accounting 15(6) 751-765.

Atte, B. (2015). Enhancing Shareholder's Participation in Company Meetings in Nigeria Through Application of Information Technology. Journal of Humanities and Social Science 20(9).

Baums, T. (2000). General Meetings in Listed Companies - New Challenges and Opportunities, Company Law Reform in OECD Countries: A Comparative Outlook of Current Trends. Stockholm, Sweden.

Brudney, V. (1996). Contract and Fiduciary Duty in Corporate Law. BCL Rev., 38, 595.

Boyatzis, R. E. (1998). Transforming qualitative information: Thematic analysis and code development. Thousand Oaks, CA, US: Sage Publications, Inc.

Conyon, M. J., \& Leech, D. (1994). Top Pay, Company Performance and Corporate Governance. Oxford Bulletin of Economics and Statistics, 56(3), 229-247.

Chong, B. C., Ngee, P. K. T., \& Ling, P. S. W. (2006). Chan \& Koh On Malaysian Company Law: Principles \& Practice. $2^{\text {nd }}$ Edition.

Crutchley, C. E., \& Hansen, R. S. (1989) A Test of the Agency Theory of Managerial Ownership, Corporate Leverage, and Corporate Dividends. Financial Management, 18(4), 36-46. http://dx.doi.org/10.2307/3665795

Carolyn, J. C. (2005). Annual General Meeting as an Accountability Mechanism. Working Paper No.23, University of Wellington, New Zealand.

Davies, P., Worthington, S., \& Micheler, E. (2012). Gower And Davies: Principles of Modern Company Law $8^{\text {th }}$ Edition. London: Sweet \& Maxwell.

Dent, C. (2017). A Law Student-Oriented Taxonomy for Research in Law. Victoria U. Wellington L. Rev., 48, 371.

Dicicco-Bloom, B., \& Crabtree, B. F. (2006). The Qualitative Research Interview. Medical Education, 40(4), 314-321.

Du Plessis, J. J., Hargovan, A., \& Harris, J. (2018). Principles of contemporary corporate governance. Cambridge University Press. 
Easterbrook, F. \& Fischel, D. (1993). Contract and Fiduciary Duty. Journal of Law and Economics 36, 425.

Etukudo. A (2000). Issues in Privatization and Restructuring in Sub-Saharan Africa - Interdepartmental Action Programme on Privatization, Restructuring and Economic Democracy Working Paper IPPRED 5. http://www.ilo.org/

Fama, E. (1980). Agency Problems and The Theory of The Firm. Journal of Political Economy 88, 288 At 290.

Fox, J. (2008). Applied Corporate Governance: Call for Reform Of AGM. Keeping Good Companies, 60(5), 270.

Galbreath, J. (2017). The Impact of Board Structure on Corporate Social Responsibility: A Temporal View. Business Strategy and the Environment, 26(3), 358-370.

Goranova, M., Abouk, R., Nystrom, P. C., \& Soofi, E. S. (2017). Corporate Governance Antecedents to Shareholder Activism:A Zero-Inflated Process. Strategic Management Journal, 38(2), 415-435.

George, H. (Ed.) (1977). Associations and Law: The Classical and Early Christian Stages. Toronto: University of Toronto Press.

Ghadas, Z. A. A. (2007). Real or Artificial-Jurisprudential Theories on Corporate Personality. US-China Law Review, 4, 6.

Green, J., \& Thorogood, N. (2018). Qualitative Methods for Health Research. Sage, London

Hampel Report on Corporate Governance: Finance Report (1998).

Hayati A. S. \& Hasani, M. A. (2015). A Legal Perspective of Shareholders' Meeting in The Globalised And Interconnected Business Environment. Global Conference on Business \& Social Science-2014, GCBSS-2014, 15th \& 16th December, Kuala Lumpur.

Henderson, H. (2018). Difficult Questions of Difficult Questions: The Role of the Researcher and Transcription Styles. International Journal of Qualitative Studies in Education, 31(2), 143-157.

Iwai, K. (1999). Persons, Things and Corporations: The Corporate Personality Controversy and Comparative Corporate Governance. The American Journal of Comparative Law, 47(4), 583-632.

Jensen, M. C., \& Meckling, W. H. (1976). Theory of The Firm: Managerial Behavior, Agency Costs and Ownership Structure. Journal of Financial Economics 3, 305-360. 
Johnson, A. (2007). After OFR: Can UK Shareholder Value Still Be Enlightened? European Business Organisation Law Review 7, 817 At 821 .

Joseph, H. (2009). The Uses and Abuses of Agency Theory. Business Ethics Quarterly, 19, 497-528.

Kahn-Freund, O. (1940). Articles of Association and Contractual Rights. The Modern Law Review 4(2), 145-148.

Kaler, J. (2002). Responsibility, Accountability and Governance. Business Ethics: A European Review, 11(4), 327-334.

Katsuhito, I. (1999). Persons, Things and Corporations: The Corporate Personality Controversy and Comparative Corporate Governance, American Journal of Comparative Law, 47(4), 583-632.

Kucukyalcin, E. (2018). Converging the Shareholder and Stakeholder Theories. In Sustainability and Social Responsibility: Regulation and Reporting 203-223. Springer, Singapore.

Lafarre A. (2014). Shareholder Activism at European Agms: Voting Turnout and Behaviour of (Small) Shareholders. Master's Thesis Ondernemingsrecht, Tilburg University.

Lazonick, W., \& O'sullivan, M. (2000). Maximizing Shareholder Value: A New Ideology for Corporate Governance. Economy and Society, 29(1), 13-35.

Lea, S. (2012). Qualitative Data Analysis. Seminar for The Academic Swiss Caucasus Net. Armenia.

Luo, Y. (2005). Corporate Governance and Accountability in Multinational Enterprises: Concepts and Agenda. Journal of International Management, 11(1), 1-18.

Lucian, A. B. (2005). The Case for Increasing Shareholder Power. Harvard Law Review, 118 (3) 833-914.

Magaji, S. (2018). Improving Member's Participation in the Annual General Meeting under Nigerian Corporate Law. Unpublished $\mathrm{PhD}$ Thesis. Universiti Utara Malaysia,

Maximilian, K. (1949). Person in Imagination or Persona Ficta of the Corporation," 9 La. L. Rev. 437.

Nelson, D. (2015). The Dilemma of the Shareholders Under the Nigerian Company Law, Journal of Policy and Globalisation.

Newman, C. E, \& Chibuike, O. O. (2014). Corporate Governance Reforms in Nigeria: A Study of Shareholders Right of Entry. http://papers.ssrn.com/sol3/ papers.cfm? abstract_ id= 2397377 
Ndzi, E. (2017). The impact of the Salomon Principle on Directors' Remuneration in the UK. International Journal of Law and Management, 59(2), 257-270.

Okike, E. N. M. (2007). Corporate Governance in Nigeria: The Status Quo' Corporate Governance: An International Review, 15(2) 173-193.

Oliver, H. (1995). Corporate Governance: Some Theory and Implications. Economic Journal, 105(430), 678-689.

Owusu, A., \& Weir, C. (2018). Agency Costs, Ownership Structure and Corporate Governance Mechanisms in Ghana. International Journal of Accounting, Auditing and Performance Evaluation, 14(1), 63-84.

Proctor, G., \& Miles, L. (2003). Corporate Governance. London: Cavendish Publishing Limited.

Rachagan, S. \& Mohd Sulaiman, A. (2018). Expanding Shareholders' Power: An Analysis of Reform Proposals in Malaysia. Review of Law \& Economics. Retrieved 11 Mar. 2018, from doi:10.1515/rle-2015-0041

Rachagan, S., Pascoe, J. \& Joshi, A. (2010). Concise Principles of Company Law in Malaysia. $2^{\text {nd }}$ edition.

Radin, M. (1932). The Endless Problem of Corporate Personality. Columbia Law Review, 32(4), 643-667.

Rashidah A., \& Mohammad R.Salim. (2010). Corporate Governance in Malaysia: Theory, Law and Context. Malaysia: Sweet \& Maxwell.

Respondent 1 (Professor of Law) Interviewed by Researcher, Nigeria 2016.

Respondent 2 (Lecturer), Interviewed by Researcher, FCT Abuja, Nigeria, October 27, 2016.

Respondent 3 (Lecturer), Interviewed by Researcher, Nigeria, October 26, 2016.

Respondent 4 (Lecturer), Interviewed by Researcher, Nigeria.

Respondent 5 (Lecturer), interviewed by researcher, Kano, Nigeria, October 25, 2016.

Respondent 7 (Shareholder activist), interviewed by researcher, FCT Abuja, Nigeria, October 27, 2016.

Respondent 8 (Shareholder Activist), Interviewed by Researcher, Nigeria, December 12, 2016.

Respondent 12 (Company Director), interviewed by researcher, Kano, Nigeria, November 22, 2016.

Respondent 16 (Regulator), interviewed by researcher, Kano, Nigeria, November 21, 2016. 
Respondent 17 (Regulator), interviewed by researcher, FCT Abuja, Nigeria, November 22, 2016.

Richard, S. (2010). Practical Guide to Corporate Governance $4^{\text {th }}$ Edition. England: Sweet \& Maxwell.

Robert, H. (1979). New Concept of Corporations: A Contractual and Private Property Model. 30, Hastings L. J. 1327.

Robin, H. Q. C. (2013). Hollington on Shareholder's Rights, $17^{\text {th }}$ Edition. England: Sweet \& Maxwell.

Rotimi, B. (2015). A Minority Shareholder. http://www.daargroup. com/daar-group/latest-news/vanguardngr-shareholdersassociations-losing-focus

Ruth, P. (2011). Shareholders Associations and Rest of Us. http:// www.vanguardngr.com/2011/09/

Sola, E. O. (2016). Role of Shareholders in Implementing the Code of Corporate Governance. http://www.businessdayonline. com

Schane, S. A. (1987). The Corporation Is a Person: The Language of Legal Fiction, 61 Tul. L. Rev. 563.

Seidman, I. (2013). Interviewing as Qualitative Research: A Guide for Researchers in Education and The Social Sciences. New York \& London. Teachers College, Columbia University.

Shleifer, A., \& Vishny, R. W. (1997). A Survey of Corporate Governance. The Journal of Finance, 52(2), 737-783.

Shuangge W. (2013). Shareholder Primacy and Corporate Governance: Legal Aspects, Practices and Future Direction. New York: Routledge Taylor \& Francis Group.

Simon, H. A. (1951). A Formal Theory of The Employment Contract. Econometrica 19: 293- 305.

Steven V. M. \& Neil W. S. (1991). Agency Costs of Free Cash Flow: Acquisition Activity and Equity Issues. Journal of Business 64(2), 213-227.

Sturges, J. E., \& Hanrahan, K. J. (2004). Comparing Telephone and Face-to-Face Qualitative Interviewing: A Research Note. Qualitative Research, 4(1), 107-118.

Susan P. S. (2005). Agency Theory. Annual Review of Sociology 31, 263-284.

Van Der Weide, M. (1996). Against Fiduciary Duties to Corporate Stakeholders. Journal of Corporate Law, 21, 27 At 57.

Wells, H. (ed.). (2018). Research Handbook on the History of Corporate and Company Law. Edward Elgar Publishing.

Yaqin, A. (2007). Legal Research and Writing. LexisNexis. 


\section{Decided Cases}

Hutton V. West Cork Railway Co (1882) 23 Ch D 654.

Kotoye V. Saraki (1994) 7 NWLR 414 at 467.

Longe V. FBN PLC (2006) LPELR-7682 CA.

M. A. Omisade \& Ors V. Harry Akandelpelr (1987) 2639 S.C.

New Resources Int'l Ltd \& Anor V Ejike Oranusi Esq (2010) LPELR-4592, C.A.

NIB Investment West-Africa V. Omisore (2006)4 NWLR Pt. 969 172 at 200.

Salomon V. Salomon (1879) AC 22.

Tsokwa Oil Marketing Co. V. U.T.C. (Nig.) Plc (2002) 12 NWLR Pt. 52437 C.A.

Yalaju Amaye V. A. R.E.C (1990) 4 NWLR Pt. 145422.

(Footnotes)

1 Robin, H. Q.C. (2013). Hollington on Shareholders' Rights, $17^{\text {th }}$ edition. United Kingdom: Sweet \& Maxwell Limited; Magaji, S. (2018). Improving Member's Participation in the Annual General Meeting under Nigerian Corporate Law. Unpublished PhD Thesis. Universiti Utara Malaysia,

2 European Corporate Governance Institute, http://www. ecgi.org/activism/index.php. (accessed March_25, 2017); Goranova, M., Abouk, R., Nystrom, P. C., \& Soofi, E. S. (2017). Corporate Governance Antecedents to Shareholder Activism: A Zero-Inflated Process. Strategic Management Journal, 38(2), 415-435.

3 Worthington, S. (2001). Shareholders: Property, Power and Entitlement, part 1 \& 2, Vol. 22 Company Lawyer 258.

4 Jensen, Mc. and Meckling, W.H. (1976). Theory of the Firm: Managerial Behaviour, Agency Costs and Ownership Structure. Journal of Financial Economics (3) 305.

5 Beebchuk, L.A. (2005). The Case for Increasing Shareholder Power. Harvard Law Review, 118833.

6 Fama, E.F. and Jensen, M.C. (1983). Separation of Ownership and Control. Journal of Law and Economics, (26) 301.

$7 \quad$ Hirschmann, A.O. (1976). Exit, Voice and Loyalty: Responses to Decline in Firms, Organisations, and States.. Cambridge, MA: Harvard University Press. 